16 Наукові записки ХНПУ ім. Г.С. Сковороди. Літературознавство, 2019, вип. 3(93)

UDC 821.111

N.Yu. Bondar

\title{
THE SPECIFIC CHARACTER OF THE ARCHETYPE OF HOME IN THE NOVEL “THE HOUSE OF DOCTOR DEE” BY P. ACKROYD
}

The novel "The House of Doctor Dee" by the English writer Peter Ackroyd (1993) tells the story of the fate of the famous alchemist and scientist of the $16^{\text {th }}$ century, Doctor John Dee and modern researcher Matthew Palmer. In literary circles, the novel "The House of Doctor Dee" by P. Ackroyd was not passed over. Such researchers as O.Yu. Akhmanov [2], A.Yu. Antoshkina [1], V.V. Strukov [11], A.Yu. Koshman [8] focused mainly on various poetological aspects of this work. The images of homunculus, Doctor Dee, London in the novel have been considered by researchers N.R. Gumerova [5], G.G. Ishimbaeva [6], I.V. Lipchanskaia [9]. A.M. Ramazanov and L.V. Bondarenko investigated historical intertextuality in the "The House of Doctor Dee" [10]. However, despite the fact that a fairly wide circle of researchers turned to various aspects of the novel "The House of Doctor Dee", the specific character of the archetype of home were not previously studied in it.

The purpose of the article is to determine the specific character of the archetype of home in the novel "The House of Doctor Dee" by P. Ackroyd in an individually-authored interpretation.

The classical understanding of home is a connection with the family, generation, protection and support, shelter and spiritual comfort. In the second half of the $20^{\text {th }}$ century the archetype of home is significantly problematic. "Home" ceases to be perceived as an exclusively "private" locus, even if it has absorbed all the wealth of the souls of its inhabitants, additional inclusions appear, most often of an existential universal plan. The literature of the postmodern era with its "sensitivity" to the world around it, i.e. with the desire to outline the problems of a wide range (philosophical, historical and others), continues to include "home" in the complex context of life. In this regard, P. Ackroyd's novel "The House of 
Doctor Dee", in which mysticism and reality are intertwined together, is of particular interest.

The novel is narrated in the first person by two characters in turn, a young researcher Matthew Palmer and Doctor John Dee. From the first pages of the novel, the reader gets acquainted with the house, which was inherited by Matthew Palmer, who works in the British Library. The house is located in Clerkenwell area, on Cloak Lane. The name of the street (it means a cloak, a mantle, a cover, as well as a mask, a guise) suggests that the house is shrouded in some mystery, which Matthew reveals later. From the very beginning, the heir notices "the strangeness of this house". From the street it seems that this is a $19^{\text {th }}$-century building, but upon closer examination, doubts creep in about the age of the house: "The door and fanlight seemed to be of the mid eighteenth century, but the yellow brickwork and robust mouldings on the third storey were definitely Victorian; the house became younger as it grew higher, in fact, and must have been rebuilt or restored in several different periods" [13, p. 1]. The walls of the first floor, without brick cladding, "made of huge stones", were erected until the eighteenth century: "... I looked back at the house as we left, and noticed for the first time that the eighteenth-century facade of the ground floor had been designed as a casing or shell for the sixteenth-century interior" [13, p. 2]. After examining the documents for the building in the British Library, Matthew finds out that this house belonged to the scientist and alchemist of the $16^{\text {th }}$ century Doctor John Dee, whom many of his contemporaries considered as a specialist in black magic. Palmer also comes to know that the house suffered a fire, hence the modern add-ons.

Doctor Dee is busy searching for ancient London and creating an artificial man, a homunculus. The idea of creating such a "biorobot" is not new. Thus, in Jewish mythology, a golem, a clay giant, created by Rabbi Leo to protect the Jewish people is mentioned; Paracelsus wrote about the homunculus in the $16^{\text {th }}$ century; a golem, in fact, is the Frankenstein monster from Mary Shelley's novel. However, with the evolution of the human worldview, this image is also rethought - like many archetypes. In this novel, the homunculus is perceived not only as a tool for fulfilling the 
will of its creator, but also as a model of an ideal person who must come to know the world and himself and, relying on this knowledge, develop in accordance with the eternal ideals of mankind. Doctor Dee spends most of his time in his library, which he is very proud of: "Yet there are few things in this house, few things in this kingdom, that can compare with my library" [13, p. 7]. There are globes made by famous masters, hourglass, and ancient monuments in it. But the true glory of the scientist lies within his books: "printed or anciently written, bound or unbound... Some are in Greek, some in Latin, some in our native tongue" [13, p. 7], as far as "books do not perish like humankind... True books are filled with the power of the understanding which is the inheritance of the ages" [13, p. 7]. Doctor Dee is also proud of his chamber: "It is an excellent room to sit in for meat, having great oaken chests and chairs curiously carved in the old style; the walls are hung with painted cloths where several histories, as well as herbs and beasts, are stained... There is a fine chair in one corner, trimmed with crimson velvet and embroidered with gold, yet it is seldom used except for high company... we lay our heads upon pillows, and we dine off pewter where once clay was fine enough... We have Turkey work, brass, soft linen, cupboards garnished with plate, and the chambers of our houses are so decorated with inlaid tables and carefully worked glass that they dazzle the eye on first entering" [13, p. 8]. This room for the scientist is proof that he achieved true prosperity with his work, his pursuit of knowledge, his scientific research: after all, he slept on straw mattresses in an adolescent home, and now Doctor Dee is ready to receive even "distinguished guests" in his house.

The scientist Doctor Dee lives with his wife Katherine and the servants Philip and Audrey. John Dee calls his residence "my own sad rambling house". This characteristic is due to the fact that children's voices are not heard in the house: "In Crutched Friars I buried my still-born children, two male and one female..." [13, p. 7]. The traditional model of home is based on archetypal foundations, when protective forces and Wise Mentors (father, mother) present. However, the reader finds out that the father of Doctor Dee does not live with his son, he is in a charity shelter, his mother died a long ago. When John Dee visits his father, 
the parent accuses him of ingratitude. Even for his father's funeral, Dee doesn't spend a penny: "I had saved four shillings on the charge for the winding-sheet, and six shillings on the charge of the burial" [13, p. 12]. After the death of his father, Doctor Dee is in a good mood, he is tempted to go somewhere "on this day of great joy and departing" [13, p. 12]. He cuts his hair at the barber, drives to Winchester Pier, and then goes to the Paris Garden, where they built a theater. On the way, Doctor Dee meets his former assistant, with whom they watch a historical tragedy about the murder of a king-father by a son and a ghost who rises from the grave to curse his father-killer. This play has a great influence on Dee, he even leaves the theater in a panic fear that his own father might suddenly appear before him. But the scientist's guilt is at a subconscious level. Even before the death of his father, a beggar wanders into his garden, and he speaks in some ancient dialect. Doctor Dee becomes interested and asks him to write a few words in a language unknown to him, but after the beggar's departure, on sheets he distinguishes only the "all closely inscribed" words "house" and "father" [13, p. 9]. In archetypal consciousness, as a rule, the concept of "home" is positive. As indicated above, it concentrates ideas about protection, stability, peace of mind; in such a house there are guiding and protective forces (mentors in the guise of the Wise Father, Mother, or other assistant characters). Doctor Dee's house is deprived of protective forces, since the scientist devotes more time to his scientific research than to his close people. Doctor Dee is shocked by the vision of a world without love that his father reveals to him. He sees the world without love and perfectly understands why this sight is revealed to him by none other than his father: Doctor Dee's love for gold far exceeded the love for his parent, and his father's death aroused in his soul only disgust and fear. According to John Dee, only his wife can save him, whose presence and love he is so used to that during her life he did not even pay attention to them; but he still decides to try to save himself in order to gain lost tenderness and love. Alas, the scientist begins to understand clearly too late. Eduard Kelley, sent by his former assistant to learn the secrets of the philosopher's stone, poisons the scientist's wife, who suspected him of ignoble intentions. After her death, Katherine comes to 
Doctor Dee in a dream and opens him a world of love. He finds himself in the garden. And according to J. Tresidder, a garden is an image of an ideal world, cosmic order and harmony, a lost and gained paradise [12]. John Dee sees a variety of beautiful plants, among which red and white roses stand out. According to Western tradition, a rose is a symbol of divine, romantic and sensual love. In coloristic symbolism, red color symbolizes life, love, joy, vitality and youth, white is the color of innocence, purity and joy, but it is still associated with the image of death: «Це стародавній колір жалоби, коли вдягали покійників у біле та покривали білим саваном. У білій одежі з'являються людям примари та мерці» [3, p. 133]. The symbolism of roses and their color are associated with Katherine's great love and her untimely death. Thus, the scientist after the death of his wife learns the world of love. First, Doctor Dee believes that he was in the Garden of Philosophers, which keeps a much greater secret in itself, for the spirit of a new life dwells in the local dew, that is, the secret to creating a homunculus. Then he realizes that this is the garden of the true world, in which both rose and nettle grow, and all living nature is a symbolic image of man. But at this time, Kelley sets a fire in the house, and Doctor Dee must leave this house in search of a solid hearth. So, the home loses archetypal characteristics at all levels, from the psychological (strong family ties, attention, mutual understanding) to the physical and social ones (protection, stability).

The other narrator Matthew Palmer notices the resemblance of the house to a person, which, in our opinion, is one of the first levels of house metaphorization. This idea was developed by J.E. Cirlot: «Фасад здания означает внешний облик человека: его личность или его маску. Значение этажей определяется вертикальной и пространственной символикой. Крыша и верхний этаж соответствуют голове и разуму, а также сознательному развитию самоконтроля» [7, p. 39]. The kitchen, according to his version, is a place of transmutation, and the staircase reflects the different levels of the soul. Thus, the house is inseparably linked not only with the life and soul of a person - it becomes an analogue of its body shell, but at the archetypal level it is associated with the formation of the personality and its potential life path. G.D. Gachev points to 
the relationship of interdependence between the house, the man and the temple. In his opinion, the house for a person is a temple, as the world is the house of God, so a person builds a house in his own image and likeness, as God creates the world: «Вообще дом - это голова.... В доме вход - рот. Двери - губы: где раскрыты, где сжаты. Окна - глаза» [4, p. 39]. Matthew notices that "the central section rose up like some broad tower from its rambling origins. No. It resembled the torso of a man rearing up, while his arms still lay spread upon the ground on either side. When I walked towards the steps, it was as if I were about to enter a human body" [13, p. 1]. The house itself in this case is associated with the image of the homunculus.

The basement in Cirlot's coordinate system is associated with the unconscious and instincts [7, p. 180]. In the basement of Doctor Dee, there was a fortune-teller, or a chamber of demonstration, where he and his assistant Edward Kelly together, using a crystal stone, tried to communicate with the spirits to find out where the lost ancient London was. Matthew's father (later we learn that he is not his own father) buys this house from Mr. Abraham Crowley in 1967, and it serves him as "the perfect cover for his sexual activities" [13, p. 15]. In this basement, Matthew's father conducts sexual rituals with Daniel Moore. Not without reason, when Matthew first visits the house, he detects "a sweet or perfumed aroma within it; it was as if the dust of this old house had somehow been overlaid with syrup or marzipan", which is associated with the aroma of love experiences $[13$, p. 1]. Going down to the basement, Matthew imagines "them in The World Turned Upside Down, dancing together in the dim red light" $[13$, p. 15]. This association is connected with the name of the bar or nightclub, which is located in the basement on Charlotte Street, and near which Palmer saw Daniel Moore in a woman's dress and a wig. If in the $16^{\text {th }}$ century, Doctor Dee comes to know the world without love and the world of love, then, Matthew in the $20^{\text {th }}$ century comes to know the world turned upside down. This world frightens him; he begins to understand due the Doctor Dee that "only love can restore life. The rest is illusion, and trickery, and nonsense" [13, p. 15]. 
Matthew Palmer finds out that he was adopted, and, analyzing his life, he realizes that: "I had grown up in a world without love - a world of magic, of money, of possession - and so I had none for myself or for others. That was why I had seen ghosts rather than real people. That was why I was haunted by voices from the past and not from my own time. That was why I had dreamed of being imprisoned in glass, cold and apart. The myth of the homunculus was just another aspect of my father's loveless existence - such an image of sterility and false innocence could have come from no other source" [13, p. 19]. Matthew feels lonely. In fact, he was always alone: with his father he could discuss only general or theoretical issues, with his mother - he could conduct banal conversations about everyday affairs. He admits in a conversation with Daniel that he does not remember his childhood at all. Matthew's parenting house in Ealing, which should correspond to the classic understanding of home with protection, support and peace of mind, is actually not a home for the narrator: "I could leave that terrible house in Ealing which had hampered me and injured me for the last twenty-nine years - for the whole of my life - and come to a place which had, for me at least, no past at all" [13, p. 1]. Thus, Matthew is deprived even of the illusory perception of his home as a special place of protection and strength. The house in which Matthew lived as a child seems empty to him. Although after talking with his mother, when he already knows that he was adopted, Matthew changes his mind about his childhood. The impetus is the words of his mother that she protected him from the man who adopted him: "But I protected you. Your mother was good for something, even then. I stopped him. I only caught him with you once, but I threatened to take him to the police... I defended you" [13, p. 19]. Matthew shakes hands with his mother for the first time, even kisses her on the cheek. He formulates his new attitude to the past so: "This was the place of my childhood, which I had once despised and rejected, but now I felt oddly contented and even joyful. I saw a girl helping an old man across the road, and I could hear someone singing in the distance. It was then, I suppose, that I began to pity my father" $[13$, p. 19]. So the house in which Matthew spent his childhood 
acquires the mother-guardian and protector, but in the new house there is emptiness.

The house of Doctor Dee seems to Matthew full of mystical phenomena: either he hears voices, then, someone covers his bed or puts his father's documents before him. And when a young man knocks at a walled door, the wall opens and he hears how Doctor Dee is talking to Kelly. So the house becomes the centre, including different time layers.

Thus, the house in the novel "The House of Doctor Dee" by P. Ackroyd loses archetypal characteristics at all levels (despite the fact that Matthew is changing his attitude to his adoptive mother), from psychological (strong family ties, attention, understanding) to physical and social (protection, stability). All the fundamental mythological motifs of stability, which usually characterize the archetype of home - the symbolic constancy of the place, the important role of higher female and male creatures (parents, teachers) as a kind of "good guardians" and mentors, the presence of children as a bastion of eternal renewal - are subjected to internal and external corrosion, and destruction, and the idea of returning home becomes impossible. In addition, the house itself acquires the features of the homunculus, it disintegrates and reborn, but in each century in its own way.

\section{Literature}

1. Антошкина А.Ю. «Дом доктора Ди» Питера Акройда: хронотоп романа». URL: https://cyberleninka.ru/article/n/dom-doktora-di-pitera-akroydahronotop-romana.

2. Ахманов О.Ю. «Жанровое своеобразие романа П. Акройда «Дом доктора Ди». URL: https://cyberleninka.ru/article/n/zhanrovoe-svoeobrazieromana-p-akroyda-dom-doktora-di.

3. Войтович В. Символіка кольорів. Українська міфологія. Київ: Либідь, 2002. C. 472-475.

4. Гачев Г.Д. Национальные образы мира: Космо - Психо - Логос. М.: Прогресс - Культура, 1995. 480 с.

5. Гумерова Н.Р. «Образ гумункулуса в романе П. Акройда «Дом доктора Ди». URL: http://docplayer.ru/27398869-Obraz-gomunkulusa-v-romane-pakroyda-dom-doktora-di.html. 
24 Наукові записки ХНПУ ім. Г.С. Сковороди. Літературознавство, 2019, вип. 3(93)

6. Ишимбаева Г.Г. Постмодернистская рецепция образа доктора Ди (У. Эко, П. Акройд) URL: https://journals.ssau.ru/index.php/hpp/article/ view/5180.

7. Керлот Х.Э. Дом. Словарь символов. М.: REFL-book, 1994. С. 179-180.

8. Кошман А.Ю. Лондонский текст в романе Питера Акройда «Дом доктора Ди». URL: http://philology.snauka.ru/2014/12/1068.

9. Липчанская И.В. Образ Лондона в творчестве Питера Акройда. URL: http://cheloveknauka.com/obraz-londona-v-tvorchestve-pitera-akroyda.

10. Рамазанов А.М. Историческая интертекстуальность в романе П. Акройда «Дом Доктора Ди». Культура народов Причерноморья. 2014. № 271. С. $227-230$.

11. Струков В.В. Художественное своеобразие романов Питера Акройда (к проблеме британского постмодернизма) URL: https://www.dissercat. $\mathrm{com} /$ content/khudozhestvennoe-svoeobrazie-romanov-pitera-akroida-kprobleme-brit anskogo-postmodernizma.

12. Тресиддер Дж. Словарь символов. URL: https:// www. booksite. ru/ localtxt/tre/sid/der/tresidder d/slovar_sim/.

13. Ackroyd P. The House of Doctor Dee URL: https://royallib.com/read/ Ackroyd_Peter/The_house_of_Doctor_Dee.html\#0

\section{References}

1. Antoshkina A.Yu. «Dom doktora Di» Pitera Akroyda: khronotop romana» ["The House of Dr. Dee" Peter Ackroyd: Chronotope of the novel"]. URL: https://cyberleninka.ru/article/n/dom-doktora-di-pitera-akroyda-hronotopromana.

2. Akhmanov O.Yu. «Zhanrovoe svoeobrazie romana P. Akroyda «Dom doktora Di» ["Genre originality of the novel by P. Ackroyd "House of Dr. Dee"]. URL: https://cyberleninka.ru/article/n/zhanrovoe-svoeobrazie-romana-pakroyda-dom-doktora-di.

3. Voitovych V. Symvolika koloriv [Symbolism of colors]. Ukrainska mifolohiia. Kyiv: Lybid, 2002. S. 472-475.

4. Gachev G.D. Natsionalnye obrazy mira [National images of the world]. Kosmo - Psikho - Logos Moskva: Progress - Kultura, 1995. $480 \mathrm{~s}$.

5. Gumerova N.R. «Obraz gumunkulusa v romane P. Akroyda «Dom doktora Di» ["The image of the humunculus in the novel by P. Ackroyd "House of Dr. Dee"] URL: http://docplayer.ru/27398869-Obraz-gomunkulusa-vromane-p-akroyda-dom-doktora-di.html.

6. Ishimbaeva G.G. Postmodernistskaya retseptsiya obraza doktora Di (U. Eko, P. Akroyd) [Postmodern reception of the image of Dr. Dee (U. Eco, P. Ackroyd)] URL: https://journals.ssau.ru/index.php/hpp/article/view/5180. 
7. Cirlot J.E. Dom [Дом]. Slovar simvolov. Moskva: REFL-book, 1994. S. $179-180$.

8. Koshman A.Yu. Londonskiy tekst v romane Pitera Akroyda «Dom doktora Di» [The London text in Peter Ackroyd's novel "House of Dr. Dee"]. URL: http://philology.snauka.ru/2014/12/1068.

9. Lipchanskaya I.V. Obraz Londona v tvorchestve Pitera Akroyda [The image of London in the work of Peter Ackroyd]. URL: http://cheloveknauka.com/ obraz-londona-v-tvorchestve-pitera-akroyda, свободный. - Загл. с экрана.

10. Рамазанов А.М. Историческая интертекстуальность в романе П. Акройда «Дом Доктора Ди» [Historical intertextuality in the novel by P. Ackroyd "House of Doctor Dee"]. Культура народов Причерноморья. 2014. № 271. C. 227-230.

11. Strukov V.V. Khudozhestvennoe svoeobrazie romanov Pitera Akroyda (k probleme britanskogo postmodernizma) [The Artistic Originality of Peter Ackroyd's Novels (on the Problem of British Postmodernism)] URL: https:// www.dissercat.com/content/khudozhestvennoe-svoeobrazie-romanov-pitera-akroida-k-probleme-britanskogo-postmodernizma.

12. Tresidder J. Slovar simvolov [Dictionary of Symbols] URL: https://www. booksite.ru/localtxt/tre/sid/der/tresidder_d/slovar_sim/.

13. Ackroyd P. The House of Doctor Dee URL: https://royallib.com/read/ Ackroyd_Peter/The_house_of_Doctor_Dee.html\#0

\section{Анотація}

\section{Н.Ю. Бондар. Специфіка архетипу будинку в романі}

\section{П. Акройда «Будинок доктора Ді»}

У статті розглядається специфіка архетипу будинку в романі П. Акройда «Будинок доктора Ді». Роман англійського письменника розповідає про долю відомого алхіміка і вченого XVI століття доктора Джона Ді і сучасного дослідника Метью Палмера. Мета статті - визначити специфіку архетипу будинку в романі П. Акройда «Будинок доктора Ді» в індивідуально-авторському трактуванні. Класичне розуміння будинку - це зв'язок 3 родиною, своїм родом, захист і опора, притулок і душевний комфорт. У другій половині XX століття архетип будинку істотно проблематизується. «Дім» перестає сприйматися як виключно «приватний» локус, нехай він навіть і увібрав все багатство душі його мешканців, з'являються додаткові включення, найчастіше екзистенціального загальнолюдського плану. Література постмодерної доби з ії «чутливістю» до навколишнього світу, тобто прагненням окреслити проблеми самого широкого кола (філософські, історичні та інші), продовжує включати «будинок» в складний контекст буття. У зв’язку з цим особливий інтерес представляє роман П. Акройда «Будинок 
доктора Ді», в якому переплітаються містика і реальність. Будинок доктора Ді представляється Метью повним містичних явищ і стає центром, що включає різні часові пласти. Будинок в романі П. Акройда «Будинок доктора Ді» втрачає архетипові характеристики на всіх рівнях (незважаючи на те, що Метью змінює своє ставлення до названої матері), від психологічного (міцні сімейні узи, увага, взаєморозуміння) до фізичного і соціального (захист, стабільність). Всі фундаментальні міфологічні мотиви стабільності, які зазвичай характеризують архетип будинку, - знакова сталість місця, важлива роль вищих жіночих і чоловічих істот (батьків, вчителів) як свого роду «добрих охоронців» і наставників, наявність дітей як оплоту вічного оновлення - піддаються внутрішній і зовнішній корозії, руйнуванню, що робить неможливою ідею повернення в будинок. До того ж сам будинок набуває рис гомункулуса, він розпадається і відроджується, але в кожному столітті по-своєму.

Ключові слова: архетип, будинок, образ, метафоричний рівень, мотив, гомункулус.

\section{Аннотация \\ Н.Ю. Бондарь. Специфика архетипа дома в романе П. Акройда «Дом доктора Ди»}

В статье рассматривается специфика архетипа дома в романе П. Акройда «Дом доктора Ди». Роман английского писателя повествует о судьбах известного алхимика и ученого XVI века доктора Джона Ди и современного исследователя Мэтью Палмера. Цель статьи - определить специфику архетипа дома в романе П. Акройда «Дом доктора Ди» в индивидуальноавторской трактовке. Классическое понимание дома - это связь с семьей, своим родом, защита и опора, приют и душевный комфорт. Во второй половине XX веке архетип дома существенно проблематизируется. «Дом» перестает восприниматься как исключительно «частный» локус, пусть даже и вобравший все богатство души его обитателей, появляются дополнительные включения, чаще всего экзистенциального общечеловеческого плана. Литература постмодернистской эпохи с ее «чувствительностью» к окружающему миру, т.е. стремлением очертить проблемы самого широкого круга (философские, исторические и другие), продолжает включать «дом» в сложный контекст бытия. В этой связи особый интерес представляет роман П. Акройда «Дом доктора Ди», в котором мистика и реальность переплетаются воедино. Дом доктора Ди представляется Мэтью полным мистических явлений и становится центром, включающим разные временные пласты. Дом в романе П. Акройда «Дом доктора Ди» теряет архетипические характеристики на всех уровнях (несмотря на то, что Мэтью меняет свое 
отношение к приемной матери), от психологического (крепкие семейные узы, внимание, взаимопонимание) до физического и социального (защита, стабильность). Все фундаментальные мифологические мотивы стабильности, которые обычно характеризуют архетип дома, - знаковое постоянство места, важная роль высших женских и мужских существ (родителей, учителей) как своего рода «добрых охранителей» и наставников, наличие детей как оплота вечного обновления - подвергаются внутренней и внешней коррозии, разрушению, что делает неосуществимой идею возвращения в дом. К тому же сам дом приобретает черты гомункулуса, он распадается и возрождается, но в каждом веке по-своему.

Ключевые слова: архетип, дом, образ, метафорический уровень, мотив, гомункулус.

\section{Summary \\ N.Yu. Bondar. The Specific Character of the Archetype of Home in the Novel "House of Doctor Dee" by P. Ackroyd}

The article deals with the specific character of the archetype of home in the novel "The House of Doctor Dee" by P. Ackroyd. The novel of the English writer tells the story of the fate of the famous alchemist and scientist of the $16^{\text {th }}$ century, Doctor John Dee and modern researcher Matthew Palmer. The purpose of the article is to determine the specific character of the archetype of home in the novel "The House of Doctor Dee" by P. Ackroyd in an individually-authored interpretation. The classical understanding of home is a connection with the family, generation, protection and support, shelter and spiritual comfort. In the second half of the 20th century the archetype of home is significantly problematic. "Home" ceases to be perceived as an exclusively "private" locus, even if it has absorbed all the wealth of the souls of its inhabitants, additional inclusions appear, most often of an existential universal plan. The literature of the postmodern era with its "sensitivity" to the world around it, i.e. with the desire to outline the problems of a wide range (philosophical, historical and others), continues to include "home" in the complex context of life. In this regard, P. Ackroyd's novel "The House of Doctor Dee", in which mysticism and reality are intertwined together, is of particular interest. The house of Doctor Dee seems to Matthew full of mystical phenomena and becomes a centre, including different time layers. The house in the novel "The House of Doctor Dee" by P. Ackroyd loses archetypal characteristics at all levels (despite the fact that Matthew is changing his attitude to his adoptive mother), from psychological (strong family ties, attention, understanding) to physical and social (protection, stability). All the fundamental mythological motifs of stability, which usually characterize the archetype of the house - the symbolic constancy of the place, the important role of higher female 
and male creatures (parents, teachers) as a kind of "good guardians" and mentors, the presence of children as a bastion of eternal renewal - are subjected to internal and external corrosion, destruction, and make the idea of returning home impossible. In addition, the house itself acquires the features of the homunculus, it disintegrates and reborn, but in each century in its own way.

Key words: archetype, home, image, metaphorical level, motif, homunculus.

\section{Інформація про автора}

Бондар Наталія Юріївна - кандидат філологічних наук, доцент кафедри економіки та управління Шосткинського інституту Сумського державного університету; вул. Гагаріна, 1, м. Шостка, Сумської області, 41100, Україна; e-mail: liya_bond@ukr.net; https://orcid.org/0000-0003-1044-9461 